\title{
Rainfall pattern effects on crusting, infiltration and erodibility in some South African soils with various texture and mineralogy
}

\author{
Adornis D Nciizah and Isaiah IC Wakindiki* \\ Department of Agronomy, University of Fort Hare, Private Bag X1314, King Williams' Town Road, Alice 5700, South Africa
}

\begin{abstract}
Rainfall characteristics affect crust formation, infiltration rate and erosion depending on intrinsic soil properties such as texture and mineralogy. The current study investigated the effects of rainfall pattern on crust strength, steady state infiltration rate (SSIR) and erosion in soils with various texture and minerals. Soil samples from the top $0.2 \mathrm{~m}$ layer were exposed to $60 \mathrm{~mm} \cdot \mathrm{h}^{-1}$ simulated rainfall. The rainfall was applied either as an 8 -min single rainstorm (SR) or 4 x 2-min intermittent rainstorms (IR) separated by a $48 \mathrm{~h}$ drying period. Rainfall pattern significantly $(p<0.05)$ affected crust strength, SSIR and erosion. The IR resulted in higher crust strength and SSIR than SR. The effect of rainfall pattern on SSIR was mostly influenced by the primary minerals, namely, quartz. Therefore, the predicted shift from long duration to short duration rainstorms due to climate change is likely to enhance crust formation and soil loss in semi-arid areas such as the Eastern Cape Province of South Africa.
\end{abstract}

Keywords: hydrology, penetration resistance, quartz, soil organic matter

\section{INTRODUCTION}

Raindrops break down soil aggregates and set off the process of physical crust formation (Assouline, 2004; Carmi and Berliner, 2008; Bu et al., 2013). The ensuing breakdown and consolidation of micro-aggregates and soil particles alter soil surface hydraulic processes such as steady state infiltration rate (SSIR) and runoff (Carmi and Berliner, 2008). Consequently, both soil and rainfall characteristics that determine the nature of crust formation have been extensively investigated in many environments (Stern et al., 1991; Wakindiki and Ben-Hur, 2002; Carmi and Berliner, 2008; Wuddivira et al., 2009; Bu et al., 2013). This widespread and sustained interest in the soil crusting phenomenon signifies both its importance and the lack of a full understanding of its impact on the environment. Among the most investigated soil properties in this regard are texture (Stern et al. 1991; Kay and Angers, 1999; Lado et al., 2004; Wuddivira et al., 2009), soil organic matter (Lado et al., 2004) and mineralogy (Wakindiki and Ben-Hur, 2002; Khun and Bryan 2004; Mamedov et al., 2006; Lado et al., 2007). Wakindiki and BenHur (2002) showed that kaolinitic soils are significantly less susceptible to crust formation than smectitic ones. Similarly, Lado et al. (2007) showed that 2:1 clays are more dispersive than 1:1 clays. Crust formation decreases with increase in clay content because clay particles bind aggregates together contributing to cohesive strength of the aggregates (Boix-Fayos et al., 2001; Chenu et al., 2000; Levy and Mamedov, 2002). Despite acknowledgement that soil mineralogy influences crust formation, only a few studies have dealt with soils dominated by primary minerals. Most likely the low adsorption capacity of quartz (Buhman et al., 2006) makes it less important with regard to plant nutrition. However, the low specific surface area

To whom all correspondence should be addressed.

+27 71313 9314; e-mail: iwakindiki@ufh.ac.za Received 12 February 2013; accepted in revised form 6 December 2013 of quartz promotes rapid soil organic matter (SOM) mineralisation resulting in poor aggregate stability (Buhman et al., 2006). Soils in most parts of the Eastern Cape Province are dominated by primary minerals such as quartz (Mandiringana et al., 2005; Nciizah and Wakindiki, 2012), and are highly susceptible to crust formation (Stern et al., 1991; Mills and Fey, 2004).

On the other hand, effects of rainfall characteristics such as depth (Fan et al., 2008), intensity (Truman et al., 2007) and duration (Augeard et al., 2008) on crust formation are wellknown. However, new thinking is being prompted by the current forecasts of climate change's potential effects on soil health and water resources. For example, it is predicted that climate change will alter both rainfall patterns and intensity (Davis 2010; Allen et al., 2011). Rainfall patterns will become more sporadic and the frequency of drought periods will increase in semi-arid regions such as the Eastern Cape Province (Davis, 2010; Financial \& Fiscal Commission, 2012). Nevertheless, the exact effects of these climatic changes on surface sealing, crusting and soil erosion are not entirely understood. Kuhn and Bryan (2004) highlighted the existence of soil-climate interactions and stressed the need for the development of a general concept for climate-soil structure interaction. Their study highlighted differences in sensitivity of the soils used to changes in soil condition on drying and subsequent interrill erosion. A 2-fold increase in erosion during dry conditions was observed in clay-textured soils, reinforcing the assertion that crust formation is influenced by rainfall pattern and soil properties. Therefore, there is a need to study the corresponding response of the soil surface to such changes. In so doing, the promotion of environmentally sustainable production systems leading to minimised degradation, as enshrined in the South African Department of Agriculture, Forestry and Fisheries Strategic Plan (DAFF, 2010), may be achieved.

Although the dire impact of climate change on soil structural behaviour is acknowledged (Allen et al., 2011; Kuhn and Bryan, 2004), less effort has been made to offer quantitative investigations in South Africa with regards to the influence of climate change on crust formation. Instead, much research has 


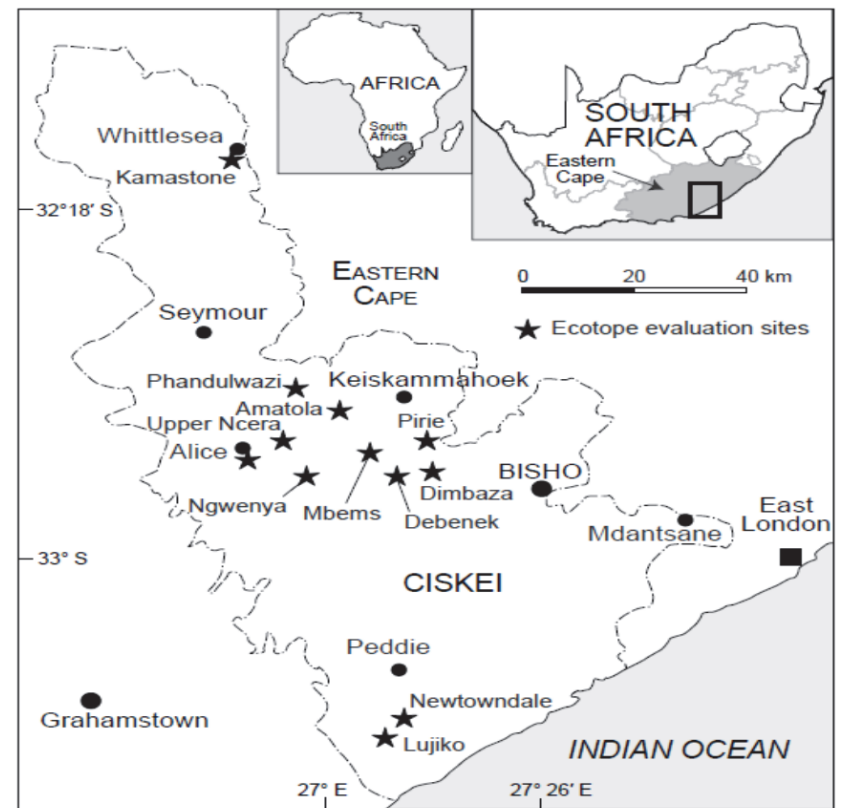

Figure 1

Soil sampling sites (Nciizah and Wakindiki, 2012)

focused on catchment hydrology (Van Tol et al., 2010), in-field water harvesting (Hensley et al., 2011) and runoff measurement on crusted soils (Hensley et al., 2000; Zere et al., 2005). The latter studies bring to light the positive aspects but ignore the massive negative contribution of soil crusting in agricultural landscapes.

Consequently, the objective of this study was to determine the effects of rainfall pattern on crust strength, SSIR and erosion in soils with various texture and mineralogy in South Africa. It was hypothesised that rainfall pattern affects crust strength, SSIR and erosion in soils, depending on their texture and dominant mineralogy.

\section{MATERIALS AND METHODS}

\section{Soil sampling}

Soil samples with varying properties were collected from the surface (0) to $0.2 \mathrm{~m}$ from 13 ecotopes in Eastern Cape Province (Fig. 1). The soil samples were air-dried for a week. The $<2 \mathrm{~mm}$ fraction was characterised for initial properties. The following determinations were done: $\mathrm{pH}$ and $\mathrm{EC}$ in water following methods described by Okalebo et al. (2000), particle size distribution according to Gee and Or (2002), SOM content as described by Cambardella et al. (2001) and soil mineralogy according to the Rietveld method as described by Zabala et al. (2007). More information about soil sampling and initial characterisation is given by Nciizah and Wakindiki (2012).

\section{Crust formation}

The soil samples were packed into splash cups (Fig. 2A) in 3 replicates and pre-wetted by capillary rise. The splash cups were then placed in a splash plate (Fig. 2B). The plate was made from a thin sheet of iron with an outside diameter of $0.3 \mathrm{~m}$ and a height of $0.1 \mathrm{~m}$ (Fig. 2C). The splash cup had a crosssectional area of $0.07 \mathrm{~m}^{2}$ and a depth of $0.3 \mathrm{~m}$. The perforations
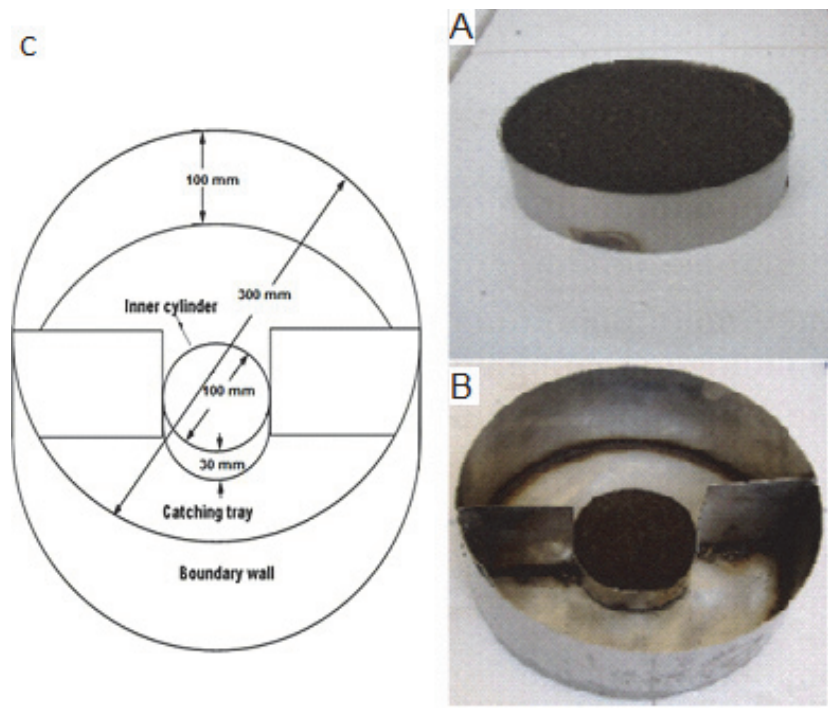

Figure 2

Splash plate with splash cup inside

at the bottom of the splash cups were covered with a piece of gauze and a filter paper to prevent soil loss and permit drainage (Nciizah and Wakindiki, 2012). The splash cups were then placed in a splash plate and exposed to simulated rainfall.

\section{Rainfall simulation}

Rainfall was applied either as 8-min single rainstorm (SR) or $4 \times 2$-min intermittent rainstorms (IR) separated by a $48 \mathrm{~h}$ drying period. These rainfall patterns and drying period treatments were adopted to mimic the predicted climate scenarios (Davis, 2010; Allen et al., 2011). The specific drying period was adapted from Knapen et al. (2008). A rainfall simulator for erosion tests (LUW, Eijkelkamp Equipment, 6987 ZG Giesbeck, Netherlands) was used. The simulator had 49 capillary tubes and applied raindrops of $5.9 \mathrm{~mm}$ in diameter. The splash cups containing the soil samples were slowly pre-wetted from the bottom with tap water until saturated, and then placed under the rainfall simulator. The soil samples were then subjected to simulated rainfall at $360 \mathrm{~mm} \cdot \mathrm{h}^{-1}$. The high intensity rainfall was used to compensate for the short falling distance, of $0.4 \mathrm{~m}$, of each simulated raindrop and the resulting low volume-specific kinetic energy of the applied shower, as suggested by Martin et al. (2010). The time-specific energy of the simulated rain was $1440 \mathrm{~J} \cdot \mathrm{m}^{-2} \cdot \mathrm{h}^{-1}$. Natural rainfall events with this time-specific kinetic energy approximate natural rainfall intensities of approximately $60 \mathrm{~mm} \cdot \mathrm{h}^{-1}$ (Martin et al. 2010). A total of 210 rainfall simulations were done. Soil crust properties were determined after air drying the soils for 1 week.

\section{Splash erosion, crust strength and steady-state infiltration rate}

After each rainstorm the splash cup was removed from the splash plate, taken for air-drying and replaced with another one. Splashed sediment was washed out of the splash cup into a jar, dried at $105^{\circ} \mathrm{C}$ for $24 \mathrm{~h}$ and weighed thereafter. Crust measurements were done after air-drying the soil sample for 1 week. A similar drying period was used by Wakindiki and Ben-Hur (2002). Crust strength was estimated in each splash cup from 
3 positions by slowly and steadily pushing a flat-point miniature hand-held penetrometer (Geotest Instrument Corp) into the top $0.05 \mathrm{~m}$ of the soil. The SSIR was determined using a mini disk infiltrometer (Decagon Devices, 2007). This instrument allows water to infiltrate while under tension to prevent the filling of the macropores. Therefore, the resultant hydraulic conductivity is characteristic of the soil matrix, and is less spatially variable (Dohnal et al., 2010; Decagon Devices, 2007). For most soils, water flow in macropores is eliminated when the suction is kept at $0.02 \mathrm{~m}$. However, sandy and clay soils require higher and lower suction, respectively (Decagon Devices, 2007). The soils used in this study were sandy loam, sandy clay loam or loam, therefore a suction rate of $0.02 \mathrm{~m}$ was adopted. Crust samples were carefully removed from the splash cups by hand and placed on a thin layer of the same soil in petri-dishes. A thin layer $(\sim 3 \mathrm{~mm})$ of silica sand was applied to the crust surface to smoothen it and give good contact between the soil crust surface and the infiltrometer. The infiltration test was started by recording the initial volume of the water in the reservoir. Thereafter, readings of the remaining volume of water in the reservoir were taken at $30 \mathrm{~s}$ intervals until $20 \mathrm{~m} \ell$ had infiltrated, as recommended by the manufacturer (Decagon Devices, 2007). Cumulative infiltration I was estimated as proposed by Zhang et al. (1997) in Eq. (1).

$$
I=C_{1} t+C_{2} \sqrt{t}
$$

where:

$C_{1}\left(\mathrm{~m} \cdot \mathrm{s}^{-1}\right)$ was a parameter related to the hydraulic conductivity $k$

$C_{2}\left(\mathrm{~m} \cdot \mathrm{s}^{-1 / 2}\right)$ was the soil sorptivity

$t$ was the time interval (s)

Equation (2) was used to compute $k$.

$$
k=\frac{C_{1}}{A}
$$

where:

$$
\begin{aligned}
& C_{1} \text { was the slope of the curve of } I \text { and } \\
& \sqrt{t} \text { that was obtained using the basic Microsoft Excel }{ }^{\circledR} \\
& \text { spreadsheet developed by Decagon Devices (2007). }
\end{aligned}
$$

Value $A$ related the Van Genuchten parameters for each soil texture class to the suction and radius of the infiltrometer disc. The Van Genuchten parameters were obtained from Carsel and Parrish (1988). The value of $A$ was then computed using Eq. (3) (Dohnal et al., 2010).

$$
A=\frac{11.65\left(n^{0.1}-1\right) \exp \left[7.5\left(n-1.9 \alpha h_{0}\right)\right]}{\left(\alpha r_{0}\right)^{0.91}} 1.35 \leq n \leq 1.9
$$

where:

$n$ and $\alpha$ were the Van Genuchten parameters. For sandy loam soils, $n$ was 1.89 and $\alpha$ was 1.89 . For sandy clay loam soils, $\mathrm{n}$ was 1.48 and $\alpha$ was 0.059 . The disc radius, $\mathrm{r}_{0}$, was $22.5 \mathrm{~mm}$, and the suction at the disc surface, $h_{0}$ was $20 \mathrm{~mm}$.

\section{Data analysis}

Analysis of variance (ANOVA) was performed using JMP 10 (SAS Institute, 2012). Mean separations were done using Fisher's protected least significant differences (LSD) at $\mathrm{P}<0.05$.

\section{RESULTS}

\section{Chemical, physical and mineralogical properties of study soils}

Some chemical, physical and mineralogical properties of the soils used in this study are shown in Table 1 . The soil mineralogy was dominated by primary minerals, mainly quartz. The most dominant textural classes were sandy clay loam and sandy loam (Table 1). Climatic conditions were mostly semi-arid whilst a few were sub-humid. Exchangeable bases, exchangeable sodium percentage (ESP) and sodium absorption ratio (SAR) of the soils is shown in Table 2. The SAR for all the soils was below $15 \mathrm{cmol}(+) \cdot \mathrm{kg}^{-1}$ whilst the ESP was below $6 \%$ for all

\begin{tabular}{|c|c|c|c|c|c|c|c|c|c|c|c|c|c|c|c|c|}
\hline & & & & & & IA & . & 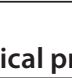 & . & 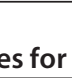 & 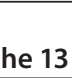 & & & & & \\
\hline Ecotope & Management & & xture & & & & & $\mathrm{pH}$ & SOM & & & Soil $n$ & ineralc & gy, \% & & \\
\hline & & Sand & Clay & Silt & & & & & & $\mathrm{H} \#$ & $\mathrm{~K}$ & $\mathrm{Mi}$ & $\mathrm{Mu}$ & $P$ & $Q$ & $S$ \\
\hline Alice J & Cultivation & 60 & 12 & 28 & 47.9 & $\mathrm{SL}^{*}$ & $\mathrm{SA}^{*}$ & 5.78 & 35.7 & 0.29 & - & 4.4 & 6.1 & 12.2 & 77.01 & - \\
\hline Amatola Jozi & Cultivation & 47 & 37 & 15 & 28.47 & SCL & $\mathrm{SH}$ & 5.80 & 66.1 & 1.91 & 32.4 & 4.36 & 2.74 & 9.29 & 28.88 & 14.7 \\
\hline Debenek & Cultivation & 56 & 18 & 26 & 49.23 & SL & SA & 5.79 & 24.0 & 0.3 & 2.1 & 4.59 & 8.5 & 84.5 & - & - \\
\hline Kame & & 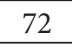 & 19 & 9 & & SL & SA & & & 0.67 & 8.56 & 10.0 & 18.8 & .9 & 5.96 & - \\
\hline Lujiko Leeuf & Cultivation & 68 & 19 & 11 & 52.23 & SL & SA & 5.45 & 38.2 & 0.63 & - & 8.61 & 5.14 & 10.4 & 75.14 & - \\
\hline Mamatha & Cultivation & 61 & 18 & 21 & 34.50 & SL & SA & 5.50 & 29.9 & 0.43 & - & 5.52 & 6.46 & 12.2 & 75.32 & - \\
\hline Mbems Koe & Pasture & 56 & 21 & 23 & 55.17 & SCL & SA & 5.65 & & 1.1 & - & 4.99 & 6.58 & 9.97 & 77.35 & - \\
\hline Mbems Koe & Cultivation & 56 & 22 & 22 & 80.97 & SCL & SA & 5.76 & 42.7 & 0.65 & - & 4.69 & 7.76 & 10.5 & 76.37 & - \\
\hline Ncera K & Culti & 48 & 26 & 26 & 61.50 & SCL & $\mathrm{SH}$ & 5.08 & 41.9 & 1.12 & 9.3 & 4.48 & 3.12 & 8.23 & 61.9 & 9.9 \\
\hline Newtondale & Cultivation & 65 & 21 & 14 & 40.34 & SCL & SA & 6.25 & 51.4 & 0.76 & - & 10.5 & 7.83 & 8.11 & 72.74 & - \\
\hline Ngwenya Jozini & Cultivation & 72 & 18 & 10 & 41.27 & SL & SA & 6.49 & 36.4 & 0.56 & - & 8.83 & 5.78 & 16.6 & 68.22 & - \\
\hline Ngwenya Swartland & Pasture & 67 & 21 & 12 & 53.57 & SCL & SA & 5.53 & 28.4 & 0.66 & - & 7.5 & 6.51 & 17.2 & 68.11 & - \\
\hline Phandulwazi Jozini & Pasture & 58 & 21 & 21 & 37.80 & SCL & SA & 5.49 & 24.7 & 0.58 & - & 0.98 & 3.95 & 7.64 & 86.85 & - \\
\hline
\end{tabular}
the soils. Consequently the soils were non-sodic.

\section{Rainfall pattern effect on soil penetration resistance in soils with different texture and mineralogy}

Rainfall pattern had a significant $(p<0.05)$ effect on the crust's penetration resistance depending on the soil's texture and

$H^{*}=$ hematite, $K=$ kaolinite, $M i=$ microline, $M u=$ muscovite, $P=$ plagioclase, $Q=q u a r t z, S=$ smectite

$S C^{*}=$ sandy clay, $S L=$ sandy loam, $S C L=$ sandy clay loam, $L=$ loam

$S A^{*}=$ semi-arid, $S H=$ sub-humid (Nciizah and Wakindiki, 2012) 


\begin{tabular}{|c|c|c|c|c|c|}
\hline \multicolumn{6}{|c|}{$\begin{array}{c}\text { TABLE } 2 \\
\text { Exchangeable bases, sodium adsorption ratio (SAR) and } \\
\text { exchangeable sodium percentage (ESP) for the } 13 \text { soils }\end{array}$} \\
\hline & \multicolumn{3}{|c|}{$\begin{array}{l}\text { Exchangeable bases } \\
\mathrm{cmol}(+) \cdot \mathrm{kg}^{-1}\end{array}$} & \multirow[t]{2}{*}{ SAR } & \multirow[t]{2}{*}{ ESP \% } \\
\hline Ecotope/soil & $\mathrm{Na}$ & $\mathrm{Mg}$ & $\mathrm{Ca}$ & & \\
\hline Alice Jozini & 1.12 & 2.07 & 77.31 & 0.12 & 2.08 \\
\hline Amatola Jozini & 0.16 & 2.80 & 87.65 & 0.01 & 1.96 \\
\hline Debenek & 0.27 & 1.87 & 35.58 & 0.04 & 2.00 \\
\hline Kamastone & 0.18 & 2.36 & 64.69 & 0.02 & 1.97 \\
\hline Lujiko Leeufontein & 0.31 & 1.54 & 32.15 & 0.06 & 2.00 \\
\hline Mamatha & 0.81 & 2.12 & 69.74 & 0.09 & 2.04 \\
\hline Mbems Koedosvlei & 0.28 & 2.64 & 123.72 & 0.02 & 1.98 \\
\hline Mbems Koedosvlei f & 0.30 & 1.48 & 31.41 & 0.06 & 2.00 \\
\hline Ncera Kinross & 0.52 & 1.20 & 27.40 & 0.11 & 2.06 \\
\hline Newtondale & 0.38 & 2.22 & 61.92 & 0.05 & 2.00 \\
\hline Ngwenya Jozini & 0.18 & 1.25 & 48.47 & 0.03 & 1.97 \\
\hline Ngwenya Swartland & 0.23 & 1.63 & 48.25 & 0.03 & 1.98 \\
\hline Phandulwazi Jozini & 0.45 & 1.11 & 26.17 & 0.09 & 2.04 \\
\hline
\end{tabular}

mineralogy (Table 3, Fig. 3a-d). The PR values for the SL and SCL were $1.84 \mathrm{~kg} \cdot \mathrm{m}^{-2}$ and $1.16 \mathrm{~kg} \cdot \mathrm{m}^{-2}$, respectively. For quartzdominated soils, the PR value was $1.90 \mathrm{~kg} \cdot \mathrm{m}^{-2}$ whilst a PR value of $1.10 \mathrm{~kg} \cdot \mathrm{m}^{-2}$ was observed for the kaolinitic soils (Fig. 3b). Crusts with a PR value of $1.14 \mathrm{~kg} \cdot \mathrm{m}^{-2}$ were formed after SR compared to $1.86 \mathrm{~kg} \cdot \mathrm{m}^{-2}$ after the IR pattern. However, there was significant interaction between soil texture and mineralogy (Table 3, Fig. 3d). Kaolinitic SCL had significantly weaker $\left(0.43 \mathrm{~kg} \cdot \mathrm{m}^{-2}\right)$ crusts than SL soils with kaolinite $\left(1.77 \mathrm{~kg} \cdot \mathrm{m}^{-2}\right)$ or quartz $\left(1.92 \mathrm{~kg} \cdot \mathrm{m}^{-2}\right)$ (Fig. 3d).

\section{Rainfall pattern effect on soil erosion in soils with different texture and mineralogy}

No significant main or interaction effects on soil erosion were observed (Table 3). Nevertheless, IR treatment caused higher soil erosion than SR. Soil erosion was higher in SCL compared to SL. Equally, kaolinitic soils eroded more than quartzdominated soils.
TABLE 3

Significance of texture, mineralogy and rainfall pattern effects on penetration resistance (PR), soil erosion (SE) and steady-state infiltration rate (SSIR)

\begin{tabular}{|l|c|c|c|c|c|}
\hline Source & Nparm & DF & $\begin{array}{c}\text { PR } \\
\left(\mathbf{k g} \cdot \mathbf{m}^{-2}\right)\end{array}$ & $\begin{array}{c}\text { SE }(\mathbf{k g} \cdot \mathbf{m} \\
\mathbf{2}^{2}\end{array}$ & $\begin{array}{c}\text { SSIR } \\
\left(\mathbf{m m} \cdot \mathbf{h}^{-1}\right)\end{array}$ \\
\cline { 3 - 6 } & & & Prob $>F$ & Prob $>F$ & Prob $>F$ \\
\hline Replication & 2 & 2 & 0.8113 & 0.7266 & 0.9859 \\
\hline Texture (T) & 1 & 1 & 0.0039 & 0.5533 & $<.0001$ \\
\hline Mineralogy (M) & 1 & 1 & 0.0009 & 0.2481 & $<.0001$ \\
\hline Rainfall pattern (RP) & 1 & 1 & 0.0025 & 0.0877 & $<.0001$ \\
\hline $\mathrm{T} \times \mathrm{M}$ & 1 & 1 & 0.0061 & 0.0603 & $<.0001$ \\
\hline $\mathrm{T} \times \mathrm{RP}$ & 1 & 1 & 0.1586 & 0.9703 & 0.2694 \\
\hline $\mathrm{M} \times \mathrm{RP}$ & 1 & 1 & 0.657 & 0.9252 & $<.0001$ \\
\hline $\mathrm{T} \times \mathrm{M} \times \mathrm{RP}$ & 1 & 1 & 0.5044 & 0.7851 & 0.0075 \\
\hline
\end{tabular}
Rainfall pattern effect on steady-state infiltration rate in
soils with different texture and mineralogy

The SSIR was $10.57 \mathrm{~mm} \cdot \mathrm{h}^{-1}$ in SCL kaolinitic soils under IR compared to $4.68 \mathrm{~mm} \cdot \mathrm{h}^{-1}$ in SL kaolinitic soils. However, under the same rainfall pattern, SSIR was $2.99 \mathrm{~mm} \cdot \mathrm{h}^{-1}$ in SCL and $2.87 \mathrm{~mm} \cdot \mathrm{h}^{-1}$ in SL in quartz-dominated soils. Moreover, the dominance of quartz resulted in lower SSIR than for kaolinitic soil within the same rainfall pattern and texture class. In the SR treatment, SSIR was $5.79 \mathrm{~mm} \cdot \mathrm{h}^{-1}$ in kaolinitic SCL soils compared to $3.67 \mathrm{~mm} \cdot \mathrm{h}^{-1}$ in quartz-dominated SCL soils. Therefore, both IR and SR rainfall patterns reduced SSIR in SCL and SL quartz-dominated soils. However, SR caused higher SSIR $\left(3.67 \mathrm{~mm} \cdot \mathrm{h}^{-1}\right)$ than SL $\left(2.31 \mathrm{~mm} \cdot \mathrm{h}^{-1}\right)$ in quartz-dominated soils. Overall, IR/kaolinite/SCL interaction had the highest SSIR $\left(10.57 \mathrm{~mm} \cdot \mathrm{h}^{-1}\right)$ compared to SR/quartz/SL treatment combination $\left(2.31 \mathrm{~mm} \cdot \mathrm{h}^{-1}\right)$ (Fig. $\left.4 \mathrm{c}\right)$.

\section{DISCUSSION}

\section{Rainfall pattern effect on penetration resistance in soils with different texture and mineralogy}

The IR rainfall pattern caused stronger crusts to develop on quartz-dominated soils compared to kaolinitic soils,
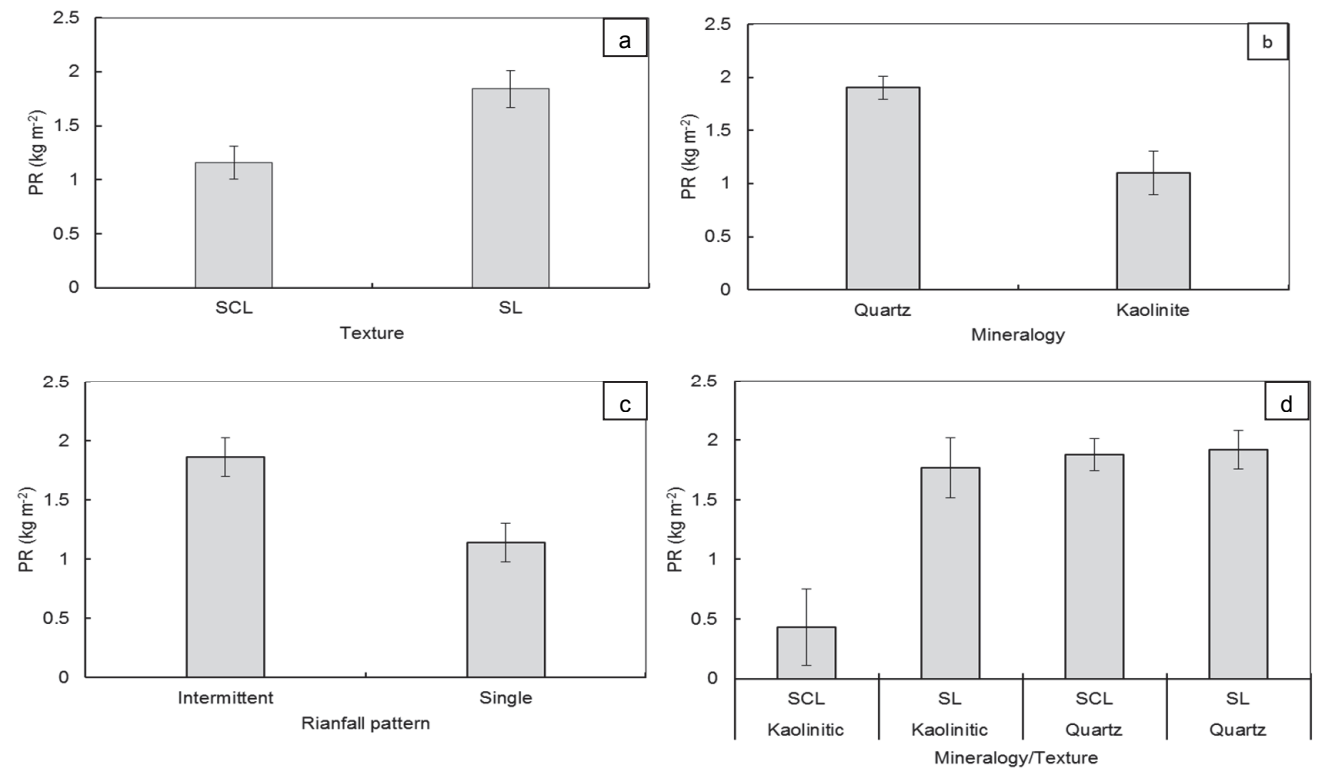

Figure 3 Effect of rainfall on crust strength in soils with different texture and mineralogy 

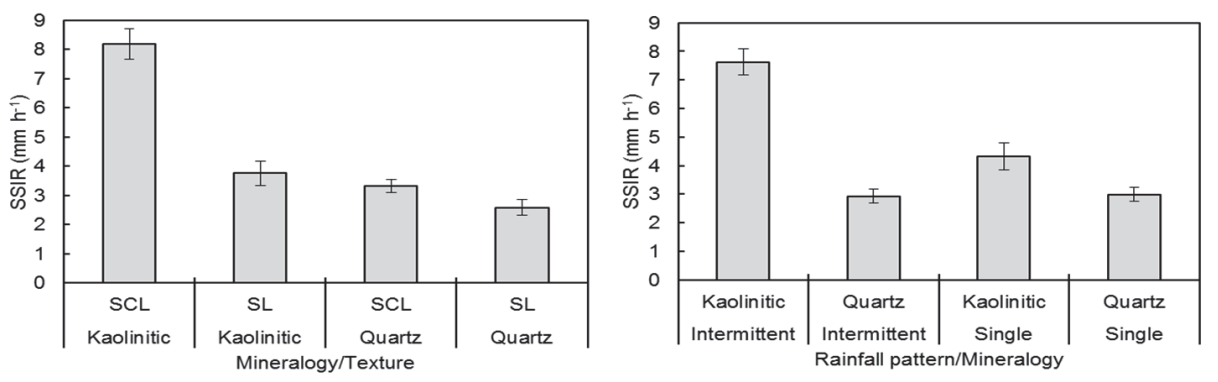

Figure 4

Effect of texture, mineralogy and rainfall pattern

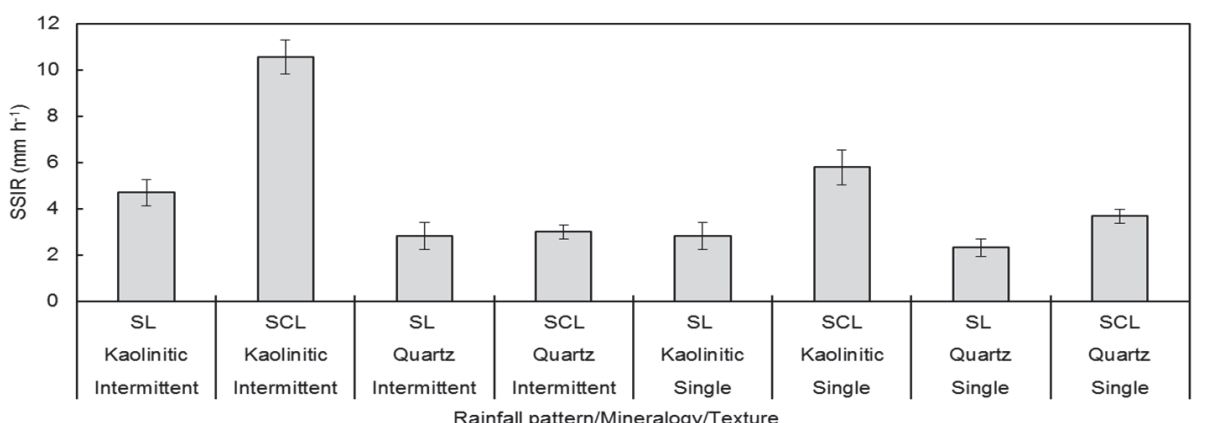

on steady-state infiltration rate (SSIR)

irrespective of the soil texture (Fig. 3d), but SR pattern led to higher crust strength for quartz-dominated than kaolinitic soils (Fig. 3b), as well as for SL than SCL soils (Fig. 3a).

The lower crust strength for SCL than SL soil could be due to high stability of the aggregates, which increased with an increase in clay content, as suggested by Kay and Angers (1999). Clay particles bind aggregates together thus contributing to cohesive strength of the aggregates, minimising breakdown upon wetting and thus reducing the tendency of the soil to crust (Levy and Mamedov, 2002). However, the results of this study showed higher crust strength in quartz-dominated soils than kaolinitic soils despite a similar soil texture (Fig. 3d). Therefore, we inferred that soil mineralogy was instrumental in crust formation in these soils. Kaolinitic soils are known to be less dispersive and highly stable (Stern et al., 1991; Wakindiki and Ben-Hur, 2002). On the other hand, primary minerals like quartz increase SOM mineralisation due to their inertness and low adsorption (Hassink, 1997; Buhman et al., 2006). Therefore, soils dominated by quartz should be highly dispersive. Nciizah and Wakindiki (2012) observed strong negative relationships $(r=-0.74)$ between SOM and quartz in these soils. Such a relationship is an indication of poor aggregate stability and proneness to slaking on rapid wetting. However, the reason for increased soil crust strength after the intermittent rainstorm (Fig. 3c) is contentious. Some authors attribute increased crust strength to changes in the soil structure during the inter-storm period, whereby there is shrinking of clays upon drying which weakens cohesive forces within the crust on further wetting (Zhang and Miller, 1993; Rajaram and Erbach, 1999). Weaker crusts are more susceptible to breakdown during intermittent rainstorms, which is why they increase in strength upon drying (Zhang and Miller, 1993). In contrast, Levy et al. (1997) observed lower erosion for soil that had undergone an aging period of $18 \mathrm{~h}$, because of densification and consolidation, which improved soil aggregate stability. However, within the mineralogy-rainfall pattern treatment combination, quartzdominated soils resulted in a stronger crust than kaolinitic soils. Since quartz is inert and without charge it cannot bond with other soil materials like SOM; hence the high mineralisation of SOM (Buhman et al., 2006) in these soils. In the end, the soils are poorly aggregated resulting in a higher likelihood of breakdown upon wetting and hence crusting. As such, densification and consolidation which improves aggregation might not have taken place in these soils and hence the high crust strength with intermittent rainstorms. Therefore, it is possible that soils dominated by quartz develop higher strength during intermittent rainstorms as opposed to single storms, which allow soil restructuring and formation of stable aggregates. The latter could have been due to the longer uninterrupted aging period. Bajracharya and Lal (1999) showed that a longer drying period may increase the formation of new aggregates which reduces soil strength.

\section{Rainfall pattern effect on soil erosion in soils with different texture and mineralogy}

The non-significant differences in soil loss between intermittent rainstorms and the single rainstorm suggest that, for the soils used in this study, soil loss after one storm or several storms, if the total duration of the rain period is the same, is similar. This could be due to consolidation which resulted in increased stability with increasing wetting and drying cycles, as was the case in this study (Knapen, 2008). However, there could be differences in the distribution of the eroded sediment among the various storms, for the intermittent storms. The lack of difference in soil loss due to soil mineralogy could be due to the influence of smectite in the kaolinitc soils (Table 1). The slightest smectite has been shown to cause dispersion and breakdown and, subsequently, soil erosion, despite presence of the stable kaolinite (Stern et al., 1991). This could have rendered the kaolinitic soils equally susceptible to soil loss as the quartz-dominated soils. Similarly, there were no differences in soil loss between the SCL and SL soils. This could have been influenced by soil mineralogy, especially the smectite, which increased the breakdown of the otherwise stable kaolinitic soils as discussed previously.

\section{Rainfall pattern effect on steady-state infiltration rate in soils with different texture and mineralogy}

Steady-state infiltration rate was influenced by the interaction of rainfall pattern with soil texture and mineralogy (Table 3; Fig. 4). Intermittent rainstorms caused higher SSIR than the 
single rainstorm. However, kaolinitic SCL soils had higher SSIR than SL soils. This higher SSIR in SCL than SL within the intermittent rainfall for kaolinitic soils could be due to the high stability and non-dispersive nature of kaolinite (Wakindiki and Ben-Hur, 2002). Moreover, aggregate stability increases as clay increases, which improves infiltration rate (Boix-Fayos et al., 2001). Similar observations were reported by Erpul and Canga (1999). Likewise, Cattle et al. (2004) observed different crusting behaviour with rainfall pattern but concluded that aging of crusts through intermittent drying and wetting events had a greater potential for affecting the initially stable silty clay soil than the structurally unstable silty loam soil, unlike in the present study. They suggested that soil texture played a significant role in the crusting behaviours of soils. Conversely, in our study quartz seemed to have more influence on SSIR under intermittent rainfall than texture. Changing mineralogy from kaolinite to quartz reduced SSIR by more than 2 times for the SCL soils and more than 1.5 times for the SL soils. These findings propose that quartz supersedes other soil factors in decreasing SSIR. A plausible explanation for this observation is that soils dominated by quartz have low aggregate stability (Buhman et al., 2006), which possibly caused the soils to collapse, leading to low SSIR. Furthermore, quartz could probably have caused increased slaking and rearrangement of particles upon rapid wetting. Differences in crusting behaviour with rainfall pattern could also have been due to the method of formation of the crust, as suggested by Levy (1997). The author observed that infiltration recovery resulting from inter-storm restructuring was lower on seals caused by mechanical breakdown of aggregates and chemical dispersion than those produced by mechanical breakdown alone. Therefore, the higher SSIR after intermittent rainstorms compared to a single rainstorm could be due to a higher SSIR recovery.

\section{CONCLUSIONS}

Our study sought to determine the effect of single and intermittent rainstorms on such crust properties as strength and steady-state infiltration, and splash erosion for soils with different texture and mineralogy. Intermittent rainstorms resulted in higher crust strength, especially for quartz-dominated sandy loam soils. Such soils are dominant in the Eastern Cape Province; therefore, any changes in rainfall patterns that favour frequent rainstorms with numerous inter-storm drying periods are likely to increase soil crusting. Rainfall pattern, texture and mineralogy did not affect soil erosion for the soils used in this study, contrary to most reports, a result which, however, warrants further investigation. Reduction in SSIR was most influenced by such primary minerals as quartz, especially for coarser-textured soils, regardless of the rainfall type. Overall, quartz played an important role in influencing crusting and SSIR in these soils while clay and kaolinite reduced crusting and increased SSIR. Therefore, changes in rainfall pattern, to frequent intermittent or sporadic rainfall, will most likely lead to high crusting and low SSIR, due to the dominance of primary minerals in most parts of the Eastern Cape Province.

\section{ACKNOWLEDGEMENTS}

Funding for this study was provided by Govan Mbeki Centre for Research and Development of the University of Fort Hare through Grant Number C104 to the second author.

\section{REFERENCES}

ALLEN DE, SINGH BP and DALAL RC (2011) Soil health indicators under climate change: A review of current knowledge. In: Singh BP (ed.) Soil Health and Climate Change. Soil Biology 29. SpringerVerlag, Berlin. 25-45.

ASSOULINE S (2004) Rainfall-induced soil surface sealing: a critical review of observations, conceptual models and solutions. Vadose Zone J. 3 570-591.

AUGEARD B, BRESSON LM, ASSOULINE S, KAO C and VAUCLIN M (2008) Dynamics of soil surface bulk density: Role of water table elevation and rainfall duration. Soil Sci. Soc. Am. J. 72 412-423.

BAJRACHARYA RM and LAL R (1999) Land use effects on soil crusting and hydraulic response of surface crusts on a tropical Alfisol. Hydrol. Proc. 13 59-72.

BOIX-FAYOS C, CALVO-CASES A, IMESON AC, SORIANO-SOTO MD and TIEMESSEN IR (2001) Spatial and short-term temporal variations in runoff, soil aggregation and other soil properties along a Mediterranean climatological gradient. Catena 33 123-128.

BU CF, GALE WJ, CAI QG and WU SF (2013) Process and mechanism for the development of physical crusts in three typical Chinese soils. Pedosphere 23 321-332.

BUHMAN C BEUKES DJ and TURNER DP (2006) Clay mineral associations in soils of the Lusikisiki area, Eastern Cape Province, and their agricultural significance. S. Afr. J. Plant Soil 23 78-86.

CAMBARDELLA CE, GAJDA AM, DORAN JW, WIENHOLD BJ and KETTLER TA (2001) Estimation of particulate and total organic matter by weight-loss-on ignition. In: Lal R, Kimble JF, Follet RF and Stewart BA (eds.) Assessment Methods for Soil Carbon. CRC Press, Boca Raton. 349-359.

CARMI G and BERLINER P (2008) The effect of soil crust on the generation of runoff on small plots in an arid environment. Catena 74 37-42.

CARSEL RF and PARRISH RS (1988) Developing joint probability distributions of soil water retention characteristics. Water Resour. Res. 24 755-755.

CATTLE S, COUSIN I, DARBOUX F and LE BISSONNAIS Y (2004) The effect of soil crust ageing, through wetting and drying, on some surface structural properties. Proc. $3^{\text {rd }}$ Australian New Zealand Soils Conference, 5-9 December 2004, University of Sydney, Australia.

CHENU C, LE BISSONNAIS Y and ARROUAYS D (2000) Organic matter influence on clay wettability and soil aggregate stability. Soil Sci. Soc. Am. J. 64 1479-1486.

DAVIS C (2010) A climate change handbook for North-Eastern South Africa. Climate Change Research Group, Council for Scientific and Industrial Research, Pretoria.

DECAGON DEVICES Inc (2007) Mini disk infiltrometer: User manual version 6. Decagon Devices, Inc., Pullman, WA

DAFF (DEPARTMENT OF AGRICULTURE, FORESTRY and FISHERIES, SOUTH AFRICA) (2010) Strategic Plan for the Department of Agriculture, Forestry and Fisheries. Department of Agriculture, Forestry and Fisheries, Pretoria.

DOHNAL M, DUSEK J and VOGEL T (2010) Improving hydraulic conductivity estimates from minidisk infiltrometer measurements for soils with wide pore-size distributions. Soil Sci. Soc. Am. J. 74 804-811.

ERPUL G and CANGA MR (1999) Effect of subsequent simulated rainstorms on runoff and erosion. Tr. J. Agric. For. 23 659-665.

FAN Y, LEI T, SHAINBERG I and CAI Q (2008) Wetting rate and rain depth effects on crust strength and micromorphology. Soil Sci. Soc. Am. J. 72 1604-1610.

FINANCIAL AND FISCAL COMMISSION (2012) Technical Report: Annual Submission on the Division of Revenue 2013/2014. FFC, Midrand.

GEE GW and OR D (2002) Particle size analysis. In: Dane JH and Top GC (eds.) Methods of Soil Analysis. Part 4 Physical Methods. ASA and ASSA, Madison, WI. 255-293.

HASSINK J (1997) The capacity of soils to preserve organic C and Nby their association with clay and silt particles. Plant Soil 191 77-87. 
HENSLEY M BENNIE ATP VAN RENSBURG LD and BOTHA JJ (2011) Review of plant available water aspects of water use efficiency under irrigated and dryland conditions. Water SA 37 (5) 771-780.

HENSLEY M, BOTHA JJ, ANDERSON JJ, VAN STADEN PP and DU TOIT A (2000) Optimizing rainfall use efficiency for developing farmers with limited access to irrigation water. WRC Report No. 878/1/00. Water Research Commission, Pretoria.

KAY BD and ANGERS DA (1999) Soil structure. In: Sumner ME (ed.) Handbook of Soil Science. CRC Press, Boca Raton, FL. A229-A276.

KHUN NJ and BRYAN RB (2004) Drying, soil surface condition and interrill erosion on two Ontario soil. Catena 57 113-133.

KNAPEN A, POESEN J and DE BAETS S (2008) Rainfall-induced consolidation and sealing effects on soil erodibility during concentrated runoff on loess-derived topsoils. Earth Surf. Proc. Land. 33 $444-458$.

LADO M, BEN-HUR M and SHAINBERG I (2007) Clay mineralogy, ionic composition, and $\mathrm{pH}$ Effects on hydraulic properties of depositional seals. Soil Sci. Soc. Am. J. 71 314-321.

LADO M, PAZ ADA and BEN-HUR M (2004) Organic matter and aggregate size interactions in infiltration, seal formation and soil loss. Soil Sci. Soc. Am. J. 68 935-942.

LEVY GJ and MAMEDOV AI (2002) High energy moisture characteristic aggregate stability as a predictor for a seal formation. Soil Sci. Soc. Am. J. 66 1603-1609.

LEVY GJ, LEVIN JDA and SHAINBERG I (1997) Prewetting rate and aging effects on seal formation and interrill soil erosion. Soil Sci. 162 131-139.

MAMEDOV AI, HUANG CDA and LEVY GJ (2006) Antecedent moisture content and aging duration effects on seal formation and erosion in smectitic soils. Soil Sci. Soc. Am. J. 70 832-843.

MANDIRINGANA OT, MNKENI PNS, MKILE Z, VAN AVERBEKE W, VAN RANSTE and VERPLANCKE H (2005) Mineralogy and fertility status of selected soils of the Eastern Cape Province, South Africa. Commun. Soil Sci. Plant Anal. 36 2431-2446.

MARTIN C, POHL M, ALEWELL C, KORNER C and RIXEN C (2010) Interrill erosion at disturbed alpine sites: Effects of plant functional diversity and vegetation cover. Basic Appl. Ecol. 11 619-626.

MILLS AJ and FEY MV (2004) Declining soil quality in South Africa: Effects of land use on soil organic matter and surface crusting. S. Afr. J. Plant Soil 21 388-398.

NCIIZAH AD and WAKINDIKI IIC (2012) Particulate organic matter, soil texture and mineralogy relations in some Eastern Cape ecotopes in South Africa. S. Afr. J. Plant Soil. 29 39-46.
OKALEBO JR, GATHUA KW and WOOMER PL (2000) Laboratory Methods of Soil and Plant Analysis: A Working Manual. TSBFKARI-UNESCO, Nairobi, Kenya.

RAJARAM G and ERBACH DC (1999) Effect of wetting and drying on soil physical properties. J. Terramechanics 36 39-49.

SAS INSTITUTE INC (2012) JMP10. Discovering JMP. Cary, NC: SAS Institute Inc.

STERN R, BEN-HUR M and SHAINBERG I (1991) Clay mineralogy effect on rain infiltration seal formation and soil losses. Soil Sci. 152 455-462.

TRUMAN CC, STRICKLAND TC, POTTER TL, FRANKLIN DH, BOSCH DD, and BEDNARZ CW (2007) Variable rainfall intensity and tillage effects on runoff, sediment, and carbon losses from a loamy sand under simulated rainfall. J Environ. Qual. 36 1495-1502.

VAN TOL JJ, Le ROUX PAL, HENSLEY M and LORENTZ SA (2010) Soil as an indicator of hillslope hydrological behaviour in the Weatherly catchment, Eastern Cape, South Africa. Water SA 36 513-520.

WAKINDIKI IIC and BEN-HUR M (2002) Soil mineralogy and texture effects on crust micromorphology, infiltration and erosion. Soil Sci. Soc. Am. J. 66 897-905.

WUDDIVIRA MN, STONE RJ and EKWUE EI (2006) Soil texture, clay mineralogy and organic matter effects on structural stability and hydraulic characteristics of selected Trinidad soils after rainfall. Trop. Agric. 83 69-78.

WUDDIVIRA MN, STONE RJ and EKWUE EI (2009) Clay, organic matter, and wetting effects on splash detachment and aggregate breakdown under intense rainfall. Soil Sci. Soc. Am. J. 73 226-232.

ZABALA MS, CONCONI MS, ALCONADA M, TORRES RM and SANCHEZ RM (2007) The Rietveld method applied to the quantitative mineralogical analysis of some soil samples from Argentina. Revista Cienciadel Suelo 25 65-73.

ZERE TB, VAN HUYSSTEEN CW and HENSLEY M (2005) Estimation of runoff at Glen in the Free State Province of South Africa. Water SA 31 17-21.

ZHANG XC and MILLER WP (1993) The effect of drying on runoff and interrill erosion of crusted soils. Catena Suppl. 24 103-114.

ZHANG R (1997) Determination of soil sorptivity and hydraulic conductivity from the disk infiltrometer. Soil Sci. Soc. Am. J. 61 1024-1030. 
http://dx.doi.org/10.4314/wsa.v40i1.7 Available on website http://www.wrc.org.za

ISSN 0378-4738 (Print) = Water SA Vol. 40 No. 1 January 2014 ISSN 1816-7950 (On-line) $=$ Water SA Vol. 40 No. 1 January 2014 